ISSN 0258-7122 (Print), 2408-8293 (Online)

Bangladesh J. Agril. Res. 42(1): 67-76, March 2017

\title{
CROP COEFFICIENT OF A POPULAR POTATO VARIETY IN BANGLADESH
}

\author{
A. R. AKANDA ${ }^{1}$, M. S. RAHMAN ${ }^{2}$, M. S. ISLAM ${ }^{3}$ AND A. J. MILA ${ }^{4}$
}

\begin{abstract}
Crop evapotranspiration $\left(\mathrm{ET}_{\mathrm{c}}\right)$ and crop coefficient $\left(\mathrm{K}_{\mathrm{c}}\right)$ values of potato (variety: BARI Alu -7, Diamant) at different growth stages were determined through lysimeter method at Irrigation and Water Management Division of Bangladesh Agricultural Research Institute (BARI), Gazipur during 2008 2009. The study was conducted by applying irrigation at 25 and 40 days after planting (DAP) allowing drainage $(\mathrm{AD})\left(\mathrm{T}_{1}\right)$, at 25, 40, and $55 \mathrm{DAP} \mathrm{AD}\left(\mathrm{T}_{2}\right)$, at 25,40 , and $60 \mathrm{DAP} \mathrm{AD}\left(\mathrm{T}_{3}\right)$, and at $25,40,55$, and $60 \mathrm{DAP} \mathrm{AD}\left(\mathrm{T}_{4}\right)$ within and adjacent of four lysimeter tanks. Irrigation at 25,40 , and 55 DAP produced the highest tuber yield and was considered to be suitable for estimating seasonal $\mathrm{ET}_{\mathrm{c}}$, and $\mathrm{K}_{\mathrm{c}}$ values. The seasonal highest $\mathrm{ET}_{\mathrm{c}}$ was found to be $162 \mathrm{~mm}$. The $\mathrm{K}_{\mathrm{c}}$ values of $0.25,0.62,0.70$ and 0.18 were determined at initial, development, midseason and late season stages of potato. These values differed slightly from the FAO recommended values. As the lysimeter provides control environment, the $\mathrm{K}_{\mathrm{c}}$ values determined by this method are most dependable and recommended for estimating $\mathrm{ET}_{\mathrm{c}}$ of potato in semi-arid climatic conditions of Bangladesh.
\end{abstract}

\section{Introduction}

Potato is an important tuber crop in Bangladesh after rice in terms of area and production (BBS, 2014). Its production is increasing day by day due to cultivation of high yielding variety, improved management practices and favourable climatic condition. Potato is an important winter crop, and irrigation is necessary for its normal growth and yield. But, irrigation water becomes costly and scarce resource due to unavailability of rainfall during winter. Utilizing this scare resource for agricultural crop production, proper irrigation scheduling of specific crop is needed. In this regard, crop coefficient values of specific crop are a probable solution. The reliable method for determining the crop coefficient values is using lysimeter. Lysimeter is a device which separates hydro logically from surrounding soil using a container of known volume of soil planted with vegetation (Michael, $2014)$ and can get accurate crop evapotranspiration $\left(\mathrm{ET}_{\mathrm{c}}\right)$ data for the specific time.

Crop coefficient $\left(\mathrm{K}_{\mathrm{c}}\right)$ represents crop actual water need in regional scale which is the ratio of actual crop evapotranspiration $\left(\mathrm{ET}_{\mathrm{c}}\right)$ and potential evapotranspiration $\left(\mathrm{ET}_{\mathrm{o}}\right)$ (Allen et al., 1998). This value is necessary for the estimation of exact irrigation requirement of various crops for that specific area. However, there are some reported $\mathrm{K}_{\mathrm{c}}$ values determined by $\mathrm{FAO}$ for different crops and are

${ }^{1}$ Chief Scientific Officer, Irrigation and Water Management Division, Bangladesh Agricultural Research Institute (BARI), Gazipur-1701, ${ }^{2}$ Senior Scientific Officer, IWM Division, BARI, Gazipur-1701, ${ }^{3}$ Former Director (Research), BARI, Gzaipur-1701, 4Scientific Officer, IWM Division, BARI, Gazipur-1701, Bangladesh. 
recommended for places where local data are not available. This FAO recommended values differ from location to location as well as from season to season. So, Tyagi et al. (2000) recommended utmost importance for the locally calibrated $\mathrm{K}_{\mathrm{c}}$ values for a given climatic condition. Many researchers determined $\mathrm{K}_{\mathrm{c}}$ values of potato using different lysimeter under various climatic conditions across the world (Carvalho et al., 2013; Kashyap and Panda, 2001; Allen et al,. 1998; Ferdous et al., 1985; Hane and Pumphre, 1984; Doorenbos and Kassam, 1979; Doorenbos and Pruitt, 1977). Karim and Akhand (1982) presented the result of evapotranspiration of potato in 18 locations of Bangladesh. They determined the average $K_{c}$ values of potato for the month of November to March after determining $\mathrm{ET}_{\mathrm{c}}$ from $\mathrm{FAO}$ recommended value. Besides, they used indigenous potato cultivar to calculate $\mathrm{ET}_{\mathrm{c}}$ value owing to nonexistence of hybrid or modern potato variety before 1990 in Bangladesh. But, in this experiment, the variety we used is short durated and high yield potential, and can easily fit in four crop-based cropping patterns in Bangladesh. Besides, the physiological characteristics of a crop differ with various soil and climatic conditions which is related to change in the ET process. In consideration of this, it is necessary to determine crop coefficient values locally to get the exact regional scale data. Besides, the information on crop water requirement is also necessary for policy planning on water management (Mainuddin et al., 2015) as well as fitting crop in a cropping pattern for a specific location. Therefore, this study was conducted to determine crop coefficient values of a popular potato variety (BARI Alu-7, Diamant) at different growth stages by micro lysimeter in the experimental field of IWM division, BARI, Gazipur, Bangladesh.

\section{Materials and Method}

The experiment was conducted at the research farm of Irrigation and Water Management Division, Bangladesh Agricultural Research Institute, Gazipur, (latitude, longitude, and elevation from MSL were $24^{\circ} 00^{\prime} \mathrm{N}, 90^{\circ} 25^{\prime} \mathrm{E}$ and $8.40 \mathrm{~m}$ ) during 2008 - 2009 using micro lysimeter. The weather data during the crop period was collected from the Agro-meteorological station which was very close to the experimental field. The weather variations during the crop period are presented in Figs.1-4. The soil was silty clay loam with field capacity and bulk density of $28 \%$ and $1.5 \mathrm{~g} / \mathrm{cc}$, respectively.

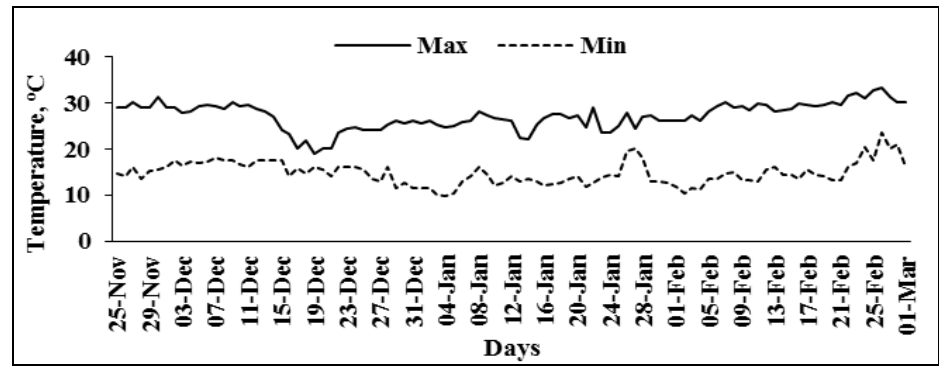

Fig. 1. Daily maximum and minimum air temperatures during 2008-2009 crop cycle. 


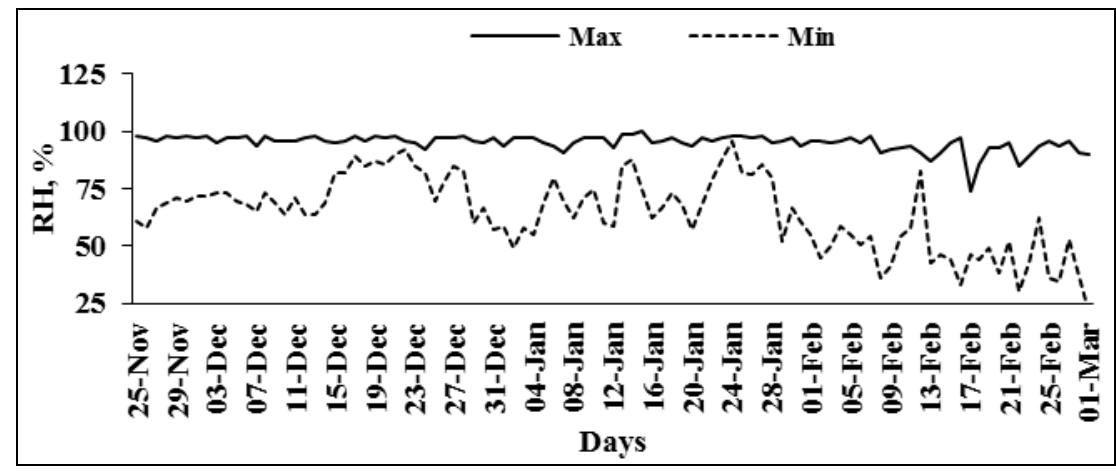

Fig. 2. Daily maximum and minimum relative humidity during 2008-2009 crop cycle.

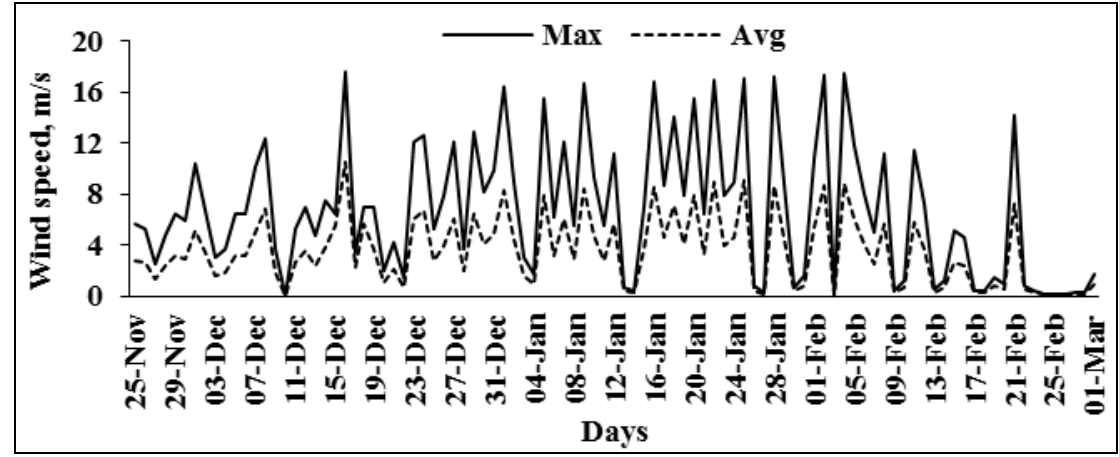

Fig. 3. Daily maximum and average wind speed during 2008-2009 crop cycle.

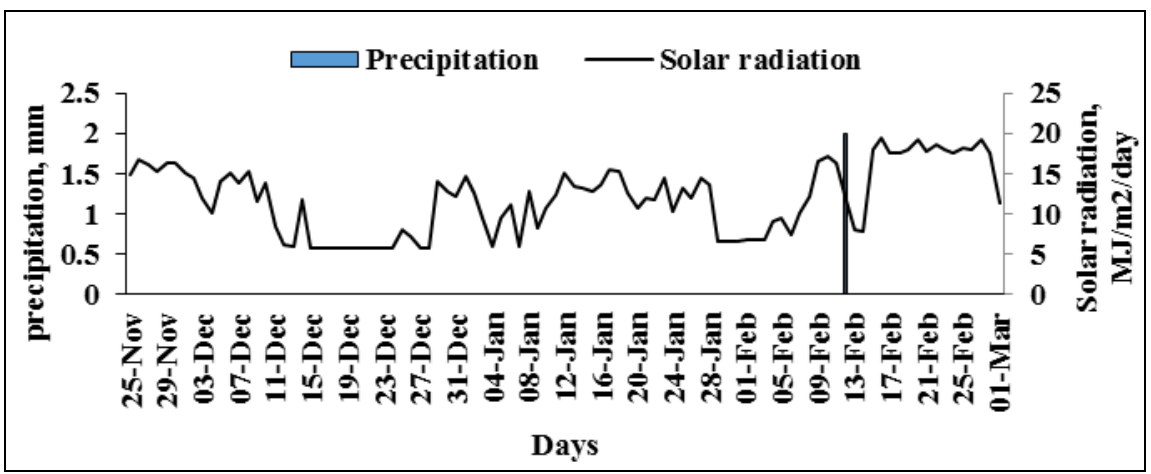

Fig. 4. Daily precipitation and solar radiation during 2008-2009 crop cycle. 
Potato seeds (variety: BARI Alu -7, Diamant) were planted on 25 November, 2008 in four lysimeter tanks maintaining row to row and plant to plant spacing of $60 \mathrm{~cm} \times 25 \mathrm{~cm}$. Recommended fertilizer was applied at the rate of $\mathrm{N}_{121}, \mathrm{P}_{27}, \mathrm{~K}_{125}$, $\mathrm{S}_{12}, \mathrm{Mg}_{7}, \mathrm{Zn}_{2}$, and $\mathrm{B}_{1} \mathrm{~kg} / \mathrm{ha}$ and cowdung $5 \mathrm{t} / \mathrm{ha}$. During final land preparation, half of $\mathrm{N}$ and total amount of other fertilizers were applied and rest of $\mathrm{N}$ was top dressed after 30 DAP. Intercultural operation (ear thing up after 30 DAP, and weeding) and pesticides were applied according to necessity. A pre-irrigation of $25 \mathrm{~mm}$ was applied in the field for proper seed germination and plant establishment. Also, to maintain a similar atmosphere, the same crop was grown in the entire field around the lysimeter tanks (Fig. 5). The crop was harvested at 01 March, 2009. The selected treatments were as follows:

$\mathrm{T}_{1}=$ Irrigations at 25 and 40 days after planting (DAP) allowing drainage (AD)

$\mathrm{T}_{2}=$ Irrigation at 25, 40 and 55 DAP AD

$\mathrm{T}_{3}=$ Irrigation at 25, 40 and $60 \mathrm{DAP} \mathrm{AD}$

$\mathrm{T}_{4}=$ Irrigation at 25, 40, 55 and $60 \mathrm{DAP} \mathrm{AD}$
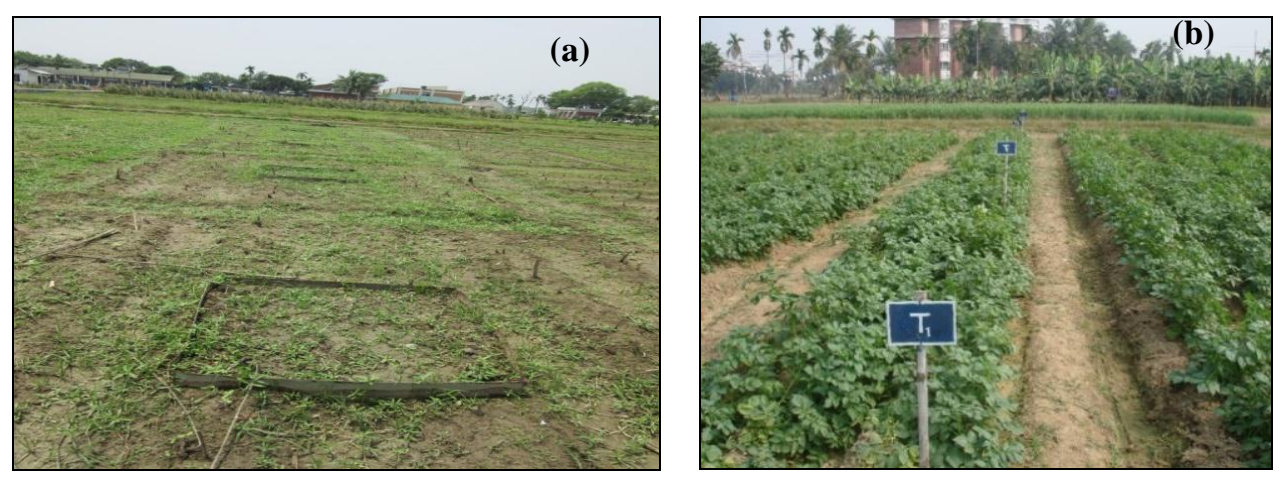

Fig. 5. Overview of experimental field (a) Lysimeter tank and (b) potato crop at vegetative stage.

The micro lysimeter contains 4 tanks, each having an area of $1.0 \mathrm{~m}^{2}$ which was designed and installed by Khan et al. (1993) at IWMD, BARI, Gazipur. As this was a controlled structure from surrounding soil so no further replication of the treatments was done (Islam and Hossain, 2010) for calculating ET $\mathrm{E}_{\mathrm{c}}$. CROPWAT software was used to calculate potential evapotranspiration $\left(\mathrm{ET}_{\mathrm{o}}\right)$ by inserting climatic data of maximum and minimum temperatures, air humidity, sunshine hours and wind speed together with the location information.

The crop was irrigated in according to the design of the treatments. Measured quantity of water was applied to the tanks to ensure drainage. Soil moisture was measured in gravimetric method during plantation, prior to irrigation and at maturity to determine the irrigation quantity and depleted soil moisture. During 
the crop season, negligible amount of rainfall was occurred (Fig.4). Crop evapotranspiration $\left(\mathrm{ET}_{\mathrm{c}}\right.$ ) was calculated by using water balance equation (Eq. 2) (Itier et al., 1997). Therefore, the stored soil moisture during the period under consideration and drainage amount were subtracted from the applied water and rainfall to obtain $\mathrm{ET}_{\mathrm{c}}$ i.e.,

$$
\mathrm{ET}_{\mathrm{c}}=\mathrm{W}_{\mathrm{a}}-\left(\mathrm{D}_{\mathrm{w}} \pm \Delta \mathrm{S}_{\mathrm{s}}\right)
$$

Where, $\mathrm{ET}_{\mathrm{c}}=$ Crop evapotranspiration in $\mathrm{mm}$ for time $\mathrm{t}$

$$
\begin{aligned}
& \mathrm{W}_{\mathrm{a}}=\text { Applied water }+ \text { rainfall }(\mathrm{mm}) \text { for time } \mathrm{t} \\
& \mathrm{D}_{\mathrm{w}}=\text { Drainage water }(\mathrm{mm}) \text { for time } \mathrm{t} \\
& \Delta \mathrm{S}_{\mathrm{s}}=\text { Stored soil moisture }(\mathrm{mm}) \text { for time } \mathrm{t}
\end{aligned}
$$

Then from the potential evapotranspiration $\left(\mathrm{ET}_{\mathrm{o}}\right)$ estimated for the specified period, the value of $\mathrm{K}_{\mathrm{c}}$ for the period was determined using the following equation.

$$
\mathrm{ET}_{\mathrm{c}}=\mathrm{K}_{\mathrm{c}} * \mathrm{ET}_{\mathrm{o}}
$$

At 65 days after sowing, the data on plant height were recorded from 8 plants in each lysimeter. The yield and yield contributing data (no of tuber/plant, tuber length, tuber diameter, and tuber weight/plant) were collected during and after harvest.

\section{Results and Discussion}

\section{Yield and yield parameters}

The yield and yield parameters of potato are presented in Table 1. All the parameters were found highest in treatment $\mathrm{T}_{2}$ except number of tuber per plant. Among other treatments, it was also noticed that larger size of tuber was obtained in treatment $\mathrm{T}_{2}$. This treatment (irrigation at 25, 40 and $55 \mathrm{DAP}$ ) also gave the highest tuber yield (35.70 t/ha). The reason was that the treatment $\mathrm{T}_{2}$ got the most favorable soil moisture conditions to produce healthy plants as seen from the data of yield parameters. Treatment $\mathrm{T}_{3}$ received three irrigations at 25, 40 and $60 \mathrm{DAP}$ which produced the second highest yield (33.90 t/ha). In case of treatment $\mathrm{T}_{3}$ and $\mathrm{T}_{4}$, the yield was almost similar, though three and four number of irrigation were applied. The lowest yield $(28.70 \mathrm{t} / \mathrm{ha})$ was obtained in treatment $\mathrm{T}_{1}$ which received only two irrigations at 25 and 40 DAP. Doorenbos and Pruitt (1977) recommended that the best growing plants producing the highest yields are suitable for calculating the crop coefficient values for different growth stages. Hence, the treatment $T_{2}$ was selected for determining the crop coefficient values of potato in this study. 
Table 1. Effect of irrigation on yield and yield parameters of potato

\begin{tabular}{c|c|c|c|c|c|c}
\hline Treatments & $\begin{array}{c}\text { Plant } \\
\text { height } \\
(\mathrm{cm})\end{array}$ & $\begin{array}{c}\text { No of } \\
\text { tuber/plant }\end{array}$ & $\begin{array}{c}\text { Tuber length } \\
(\mathrm{mm})\end{array}$ & $\begin{array}{c}\text { Tuber dia. } \\
(\mathrm{mm})\end{array}$ & $\begin{array}{c}\text { Tuber } \\
\text { weight/plant } \\
(\mathrm{g})\end{array}$ & $\begin{array}{c}\text { Tuber } \\
\text { yield } \\
(\mathrm{t} / \mathrm{ha})\end{array}$ \\
\hline $\mathrm{T}_{1}$ & 55.54 & 6.5 & 66.00 & 38.8 & 286.98 & 28.70 \\
$\mathrm{~T}_{2}$ & 73.80 & 6.9 & 72.64 & 45.17 & 441.95 & 35.70 \\
$\mathrm{~T}_{3}$ & 61.00 & 7.2 & 71.80 & 45.80 & 428.98 & 33.90 \\
$\mathrm{~T}_{4}$ & 56.60 & 7.7 & 65.60 & 46.50 & 358.05 & 33.50 \\
\hline
\end{tabular}

\section{Determination of crop ET}

Table 2 represents the total crop ET $\left(\mathrm{ET}_{\mathrm{c}}\right)$ during the growing season. It was found that the seasonal ETc of potato was $162 \mathrm{~mm}$. Badr et al., (2012) reported the total $\mathrm{ET}_{\mathrm{c}}$ of potato was $362 \mathrm{~mm}$ at the full irrigation supply in Nubaria region, west of Nile Delta, Egypt. They did experiment on late maturity potato variety 'Cara' (Solanum tubero-sum L.) during late summer from September to December, 2010. Besides, they calculated $\mathrm{ET}_{\mathrm{c}}$ from $\mathrm{FAO}$ recommended value (Allen et al., 1998). This crop received a total rainfall of $16.5 \mathrm{~mm}$ during crop period, while our crop received only a negligible amount of rainfall (Fig. 4). In our experiment, we applied only three irrigations through furrow method, while they applied irrigation through drip irrigation method up to developmental stage and after that every 2 days up to physiological maturity. Doorenbos and Pruitt (1977) reported the seasonal ET value of potato ranges from 350 to $625 \mathrm{~mm}$ depending on season. Hane and Pumphre (1984) found the seasonal ET ranges from 300 to $650 \mathrm{~mm}$ in north central Oregon. Our estimated value was found much lower than the value found by other scientists. This may be the reason of variety, location, and weather condition. Karim and Akhand (1982) determined evapotranspiration of potato in 18 districts of Bangladesh which ranges from 264.6- $408.2 \mathrm{~mm}$. Much deviation was found with the values found by Karim and Akhand (1982) within the same country. They calculated crop evapotranspiration from $\mathrm{FAO}$ recommended $\mathrm{K}_{\mathrm{c}}$ values as there was no regional value.

The negative value in soil moisture storage indicates the depleted soil moisture used by the crop. On the other hand, the positive values indicate the water stored in the soil in excess of ET.

Table 2. Determination of ET $_{\mathrm{c}}$ during the crop season by lysimeter study

\begin{tabular}{c|c|c|c|c|c}
\hline $\begin{array}{c}\text { Duration in } \\
\text { days }\end{array}$ & $\begin{array}{c}\text { Applied water } \\
(\mathrm{mm})\end{array}$ & $\begin{array}{c}\text { Effective } \\
\text { rainfall } \\
(\mathrm{mm})\end{array}$ & $\begin{array}{c}\text { Percolation } \\
(\mathrm{mm})\end{array}$ & $\begin{array}{c}\text { Soil moisture } \\
\text { storage } \\
(\mathrm{mm})\end{array}$ & $\begin{array}{c}\text { Crop ET } \\
(\mathrm{mm})\end{array}$ \\
\hline $0-25$ & 4 & 0 & 0 & -13 & 17 \\
$25-40$ & 36 & 0 & 12 & -18 & 42 \\
$40-55$ & 27 & 0 & 5 & -33 & 55 \\
$55-95$ & 54 & 0 & 8 & -2 & 48 \\
Total & - & - & - & - & 162 \\
\hline
\end{tabular}




\section{Determination of crop coefficient}

The duration of crop growth stage depends on the length of growing season of a particular crop and climate (Doorenbos and Pruitt, 1977; Smith et al.,1992). Here, the total crop growth period was 97 days and the highest $\mathrm{ET}_{\mathrm{c}}$ and $\mathrm{ET}_{\mathrm{o}}$ was recorded at the mid-season stages (Table 3 ).

Table 3. Estimation of crop co-efficient of potato

\begin{tabular}{l|c|c|c|c}
\hline Crop growth & $\begin{array}{c}\text { Duration } \\
(\text { days })\end{array}$ & $\begin{array}{c}\text { Crop ET } \\
\left(\mathrm{ET}_{\mathrm{c}}\right)(\mathrm{mm})\end{array}$ & $\begin{array}{c}\text { Reference ET } \\
\left(\mathrm{ET}_{\mathrm{o}}\right)(\mathrm{mm})\end{array}$ & $\begin{array}{c}\text { Crop coefficient } \\
\left(\mathrm{K}_{\mathrm{c}}\right)\end{array}$ \\
\hline Initial & 15 & 11.12 & 44.86 & 0.25 \\
Development & 20 & 35.32 & 56.55 & 0.62 \\
Mid-season & 35 & 90.10 & 113.15 & 0.79 \\
Late season & 27 & 26.32 & 145.8 & 0.18 \\
Total & 97 & - & - & - \\
\hline
\end{tabular}

Evapotranspiration and crop coefficients are varied according to the crop growth stages (Fig. 6 - 8). At the initial stage, $\mathrm{ET}_{\mathrm{c}}$ was about $0.63 \mathrm{~mm} / \mathrm{day}$ and fluctuated, reached at peak during the period of 64, was $1.87 \mathrm{~mm} /$ day and after that it sharply fall by $1.63 \mathrm{~mm} /$ day at 72 days after sowing. On the other hand, $\mathrm{ET}_{\mathrm{o}}$ values fluctuated within the range of $1.10-3.48 \mathrm{~mm} /$ day while at the primary stage its value was about $2.34 \mathrm{~mm} /$ day, then gradually fall during the mid-season and again rose up to $3.48 \mathrm{~mm} /$ day prior to harvest (Fig. 6). In Fig. 7, cumulative crop evapotranspiration values are increasing during the crop season. At the initial stage (25 days after sowing) it was $17 \mathrm{~mm}$ after that it sharply increased and rose to $162 \mathrm{~mm}$. Therefore, crop coefficient values were found $0.25,0.62,0.79$ and 0.18 at initial, development, mid-season, and late season stages (Table 3 ) though three stages value was given in Fig. 8 and was done by following averaging method (Biswas et al., 2014).

Carvalho et al. (2013) found the $\mathrm{K}_{\mathrm{c}}$ values of $0.35,0.45,1.29$ and 0.63 for initial, development, mid-season and late season, respectively in Rio de Janeiro (RJ), Brazil. Kashyap and Panda (2001) found the $\mathrm{K}_{\mathrm{c}}$ values of potato at initial, crop development, reproductive and maturity were $0.42,0.85,1.27$ and 0.57 , respectively at the experimental farm of the Agricultural and Food Engineering Department, Indian Institute of Technology, Kharagpur, India. Ferdous et al., (1985) found the $\mathrm{K}_{\mathrm{c}}$ values of 0.30 at emergence, 1.23 during full coverage, and 0.48 at maturity stage in Amman, Jordan. Hane and Pumphre (1984) found that $\mathrm{K}_{\mathrm{c}}$ values increased from 0.3 at emergence to over 0.8 during maximum leaf area and declines with crop maturity in north central Oregon. Doorenbos and Pruitt (1977) reported the $K_{c}$ values of potato for mid-season and at harvest was 1.05 to 1.1 and 0.7 depending on minimum relative humidity of $>70 \%$ and 1.15 to 1.2 and 0.75 depending on minimum relative humidity of $<20 \%$. Doorenbos and 
Kassam (1979) reported $\mathrm{K}_{\mathrm{c}}$ values of 0.4- 0.5, 0.7- 0.8, 1.05-1.2 and 0.85-0.95 for initial, crop development, mid-season, and late season stages, respectively.

These crop coefficient values slightly differed from those recommended by FAO (Doorenbos and Pruitt, 1977). The lower value of $K_{c}$ value compared to other findings was due to lower length of season, lower temperature, higher humidity, lower solar radiation, etc. But FAO values are the standard values and need calibration for a specific region or location as per guidelines suggested in FAO Irrigation and Drainage paper (Allen et al., 1998). The crop coefficient during the crop season was $0.50,0.65,1.15$ and 0.75 at initial, developmental, middle and tuber maturity stages, respectively (Allen et al., 1998). The values determined by lysimeter study are more dependable than the values obtained by calibration from the FAO recommended values.

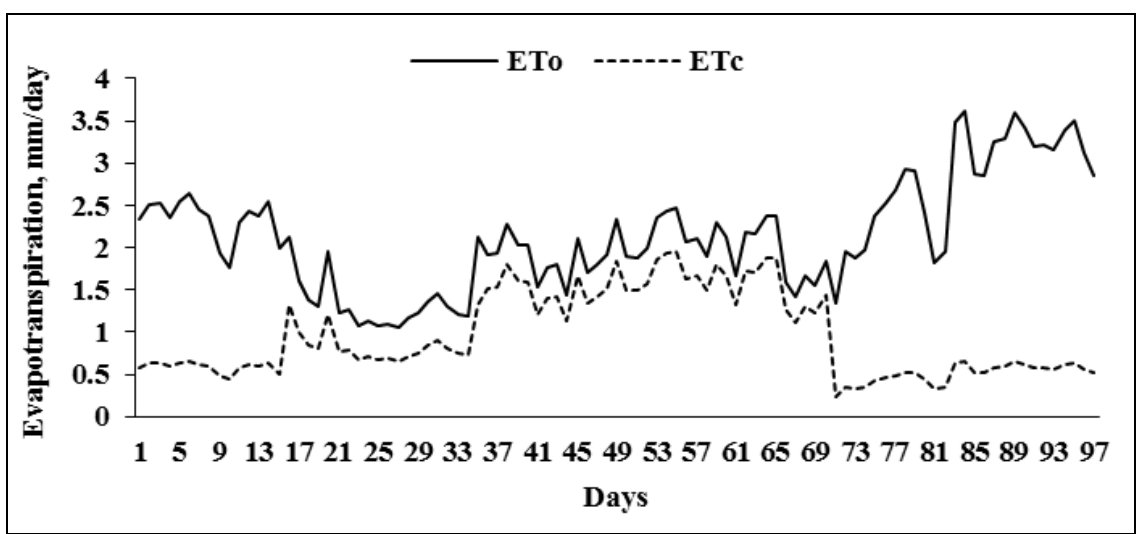

Fig. 6. Crop evapotranspiration $\left(E T_{c}\right)$ and potential evapotranspiration $\left(E T_{0}\right)$ of potato during the crop growth period.



Fig. 7. Cumulative crop evapotranspiration $\left(E T_{c}\right)$ of potato during the crop growth period. 


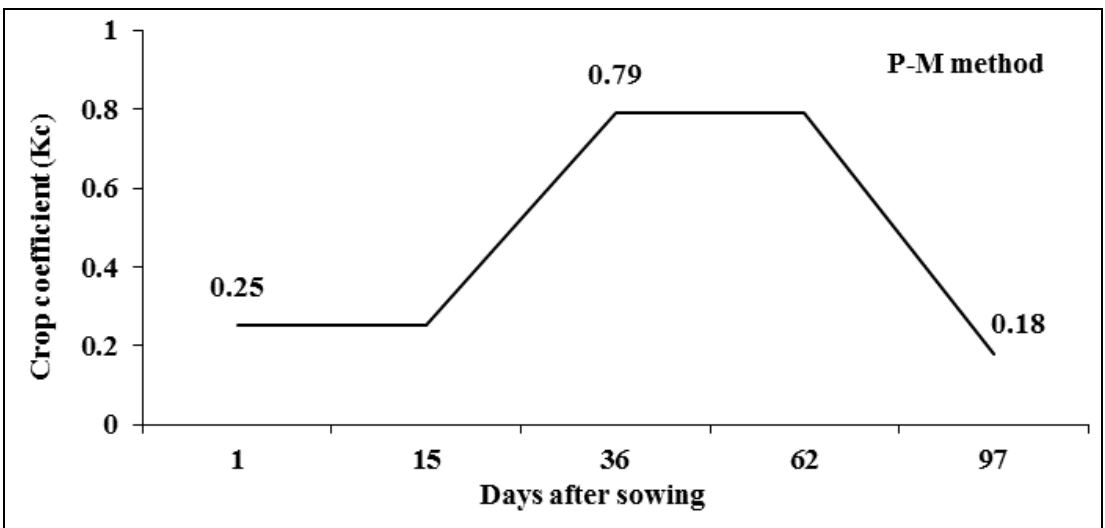

Fig. 8. Crop coefficient values of potato during the crop growth period.

\section{Conclusion}

The crop coefficient values of potato were $0.25,0.62,0.79$ and 0.18 at initial, development, mid-season and late season stages from the Lysimeter study. Lysimeter provides a control environment and the values determined by this method are most dependable and can be used for estimating crop water requirement for potato in Bangladesh. The seasonal evapotranspiration of potato was $162 \mathrm{~mm}$.

\section{References}

Allen, R. G., L. S. Pereira, D. Raes and M. Smith. 1998. Crop Evapotranspiration: Guidelines for Computing Crop Water Requirements. Proceedings of the FAO Irrigation and Drainage Paper No.56. Roma, Italy.

Badr, MA, W. A. El-Tohamy and A. M. Zaghloul. 2012. Yield and water use efficiency of potato grown under different irrigation and nitrogen levels in an arid region. Agricultural Water Management. 110: 9-15.

Biswas, S. K., M. A. Hossain, A. R. Akanda. 2014. Determination of crop co-efficient of garlic by lysimeter study. Annual research report, Irrigation and Water Management Division, BARI, Gazipur. Pp.49.

BBS. 2014. Yearbook of Agricultural Statistics. Bangladesh Bureau of Statistics. Statistics and information Division. Ministry of Planning.

Carvalho, D.F.D., D. G. D. Silva, H. S. D. Rocha, W. S. D. Almeida, E. D. S. Sousa. 2013. Evapotranspiration and crop coefficient for potato in organic farming. Engenharia Agricola, 33(1):201-211.

Doorenbos, J., A. H. Kassam. 1979. Yield response to water; FAO Irrigation and Drainage Paper No. 33. FAO, Rome, Italy.

Doorenbos, J., W. O. Pruitt. 1977. Guidelines for Predicting Crop Water Requirements. Irrigation and Drainage Paper 24. Food and Agricultural Organization of the United Nations, Rome. Pp: 144. 
Ferdous, A., I. Ghawi, M. Shatanawi. 1985. Determination of crop coefficient for potatoes in the Jordan Valley. http://agris.fao.org/agris-search/search.do?recordID= JO870006088. Accessed on 31 August 2016.

Hane, D.C., F. V. Pumphrey. 1984. Yield-evapotranspiration relationships and seasonal crop coefficients for frequently irrigated potatoes. American potato journal. 61(11):661-668.

Islam M. S., M. A. Hossain. 2010. Determination of crop co-efficient of hybrid maize by lysimeter study. Bangladesh Journal of Agricultural Research. 35(1):77-82.

Itier, B, N. Brisson, C. Doussan, R. Tournebize. 1997. Bilan hydriqueen Agrometeorologie. In: Lagouarde JM, Cruiziat P. (Eds.), Du Couvert Vegetal a la Region. INRA, Versailles, Pp. 383-397.

Karim, Z, N. A. Akhand. 1982. Net irrigation requirement of rice and evapotranspiration of wheat and potato for different locations of Bangladesh. Bangladesh Agricultural Research Council (BARC), Farmgate, Dhaka-15, Pp:1-40.

Kashyap P.S., R. K. Panda. 2001. Evaluation of evapotranspiration estimation methods and development of crop-coefficients for potato crop in a sub-humid region. Agricultural Water Management, Amsterdam, 50(1):9-25.

Khan, B. R., M. Mainuddin, M. N. Molla. 1993. Design, construction and testing of a lysimeter for a study of evapotranspiration of different crops. Agricultural Water Management, 23:183-197.

Mainuddin, M, M. Kirby, R. A. R. Chowdhury, S. M. Shah-Newaz. 2015. Spatial and temporal variations of, and the impact of climate change on, the dry season crop irrigation requirements in Bangladesh. Irrigation Science. 33:107-120.

Michael, A. M. 2014. Water requirement of crops and irrigation management. In: Irrigation Theory and Practice, $2^{\text {nd }}$ Edition, Vikas Publishing House, India, Pp: 478553.

Smith, M., R. Allen, J. L. Monteith, A. Perrier, L. Santos Pereira, A. Sageren. 1992. Expert consultation on revision of FAO methodologies for crop water requirements. Food and Agricultural Organization of the United Nations, Land and Water Development Division, Rome, Italy, Pp: 60.

Tyagi, N. K., D. K. Sharma, S. K. Luthra. 2000. Evapotranspiration and crop coefficients: measurement and computation for crop water requirements, Bulletin No. 1/2000, Central Soil Salinity Research Institute, Kamal, India, Pp: 26. 